\title{
AKTIVITAS DAN PRESTASI BELAJAR IPA SISWA KELAS VIII G SMP NEGERI 2 SIDEMEN DENGAN MODEL SIKLUS BELAJAR TRI PRAMANA
}

\author{
Nyoman Sri Darmayanti \\ Guru di SMP Negeri 2 Sidemen \\ email: darmayantizoul@gmail
}

\begin{abstract}
Abstrak
Penelitian ini tergolong penelitian tindakan kelas yang bertujuan untuk meningkatkan aktivitas dan prestasi belajar siswa dengan menerapkan Model Siklus Belajar Tri Pramana pada pembelajaran IPA. Subjek penelitian yaitu siswa di kelas VIII G pada semester I tahun pelajaran 2017/2018 di SMP Negeri 2 Sidemen. Sedangkan objeknya aktivitas dan prestasi belajar siswa. Data yang diperoleh adalah data kuantitatif berupa prestasi belajar yang dikumpulkan melalui instrumen tes dan data aktivitas siswa yang dikumpulkan dengan instrumen lembar observasi. Hasil yang diperoleh dianalisis secara deskriptif. Dari pelaksanaan penelitian rata-rata aktivitas belajar siswa pada siklus I sebesar $71,90 \%$ dengan kategori baik meningkat menjadi $77,36 \%$ di siklus II juga dengan kategori baik. Prestasi belajar mengalami peningkatan dari data awal dengan rata-rata 63, pada siklus I menjadi 72,30 dan pada siklus II menjadi 76,46. Ketuntasan belajar awal $58 \%$ menjadi $73,07 \%$ pada siklus I, dan meningkat menjadi $88,46 \%$ pada siklus II. Kesimpulan yang didapat bahwa pembelajaran dengan Model Siklus Belajar Tri Pramana mampu meningkatkan aktivitas dan prestasi belajar siswa di kelas VIII G SMP Negeri 2 Sidemen semester I tahun pelajaran 2017/2018 pada pembelajaran IPA.
\end{abstract}

Kata kunci: aktivitas belajar, prestasi belajar, siklus belajar, Tri Pramana, dan IPA.

\section{Abstract}

This research is classified as a classroom action research that aims to increase student activity and achievement by applying Tri Pramana Learning Cycle Model to science learning. Research subjects are students in class VIII G in the first semester of the academic year 2017/2018 in SMP Negeri 2 Sidemen. While the object activity and student achievement. The data obtained are quantitative data in the form of learning achievement collected through test instrument and student activity data collected with instrument observation sheet. The results obtained were analyzed descriptively. From the average research activity of student activity in cycle I was $71,90 \%$ with good category increased to $77,36 \%$ in cycle II also with good category. Achievement learn to increase from initial data with average 63, in cycle I become 72,30 and in cycle II become 76,46. 58\% initial learning completeness to $73.07 \%$ in cycle I, and increased to $88.46 \%$ in cycle II. The conclusion is that learning with Tri Pramana Learning Cycle Model able to increase student's activity and achievement in class VIII G SMP Negeri 2 Sidemen semester I of academic year 2017/2018 on science lesson.

Keywords: learning activity, learning achievement, learning cycle, Tri Pramana, and IPA 


\section{PENDAHULUAN}

Masalah pembelajaran IPA yang sedang dihadapi di kelas VIII G SMP Negeri 2 Sidemen semester I tahun pelajaran 2017/2018 adalah guru belum mampu membuat siswa menjadi aktif belajar. Berdasarkan data awal, nilai siswa mencapai ratarata 63 dengan ketuntasan belajar baru mencapai 58\%. Nilai rata-rata tesebut masih di bawah KKM mata pelajaran IPA di sekolah ini yaitu 72 . Upaya peningkatan aktivitas dan prestasi belajar diupayakan dengan menggunakan model pembelajaran inovatif berbasis kearifan lokal Tri Pramana yang dikembangkan oleh Subagia, dan Wiratma (2007b). Pemilihan model pembelajaran mempertimbangkan karakteristik materi, karakteristik peserta didik, dan karakteristik lingkungan pebelajar. Model siklus belajar Tri pramana terdiri dari langkah anumana pramana $(\mathrm{A})$, pratyaksa pramana $(\mathrm{P})$, dan sabda pramana (S) yang alurnya disusun berdasarkan karakteristik materi. Materi IPA di SMP memerlukan penyelidikan dan penalaran yang perlu dikaitkan dengan kajian pustaka untuk memecahkan fenomena alam. Dilihat dari karakteristik lingkungan pebelajar,
SMP Negeri 2 Sidemen memiliki laboratorium IPA yang menunjang pembelajaran.

Rumusan masalah dalam penelitian ini adalah apakah Model Siklus Belajar Tri Pramana dapat meningkatkan aktivitas dan prestasi belajar siswa kelas VIII G SMP Negeri 2 Sidemen semester I Tahun pelajaran 2017/2018 pada pembelajaran IPA?. Sedangkan cara pemecahan masalahnya adalah dengan menggunakan langkahlangkah Model Siklus Belajar Tri Pramana. Tujuan penelitian ini adalah mengetahui seberapa besar peningkatan aktivitas dan prestasi belajar siswa kelas VIII G SMP Negeri 2 Sidemen semester I tahun pelajaran 2017/2018 setelah diterapkannya langkah-langkah Model Siklus Belajar Tri Pramana dalam pembelajaran IPA. Manfaat penelitian bagi siswa adalah dapat meningkatkan kerja sama dengan temannya dalam kelompok kooperatif sehingga mampu meningkatkan aktivitas siswa yang berujung pada peningkatan prestasi belajar. Bagi guru penerapan Model Siklus Belajar Tri Pramana dapat menjadi model 
pembelajaran inovatif berbasif kearifan lokal masyarakat Bali.

Dengan memperhatikan hasilhasil pembelajaran yang belum optimal, Subagia dan Wiratma (2007b) mengembangkan suatu model pembelajaran inovatif yang dirumuskan berdasarkan potensipotensi kearifan lokal masyarakat Bali (Hindu) dalam bidang pendidikan. Model siklus belajar yang dirumuskan berbasis pada cara-cara belajar tradisional yang telah diuraikan dalam filsafat Hindu (Sad Dharsana), yaitu Nyaya Dharsana (Musna, 1986, Maswinara,1998). Tri Pramana adalah tiga cara belajar, yaiti belajar secara langsung berhadapan dengan objek materi ajar yang dikenal dengan Pratyasa Pramana, belajar dari membaca puku atau mendengar dari guru yang disebut sabda/agama pramana, belajar dengan perhitungan logis berdasarkan gejala-gejala yang diamati kemudian menarik simpulan. Penggunaan Model Siklus Belajar Tri Pramana dalam pembelajaran IPA dapat meningkatkan aktivitas belajar. Menurut Djamarah (1994) aktivitas artinya kegiatan atau keaktifan. Jadi segala sesuatu yang dilakukan atau kegiatan-kegiatan yang terjadi baik fisik maupun non-fisik, merupakan suatu aktivitas. Anak didik dipandang sebagai organisme yang mempunyai potensi untuk berkembang. Oleh sebab itu, tugas pendidik adalah membimbing dan menyediakan kondisi agar anak didik dapat mengembangkan bakat dan potensinya. Dalam hal ini, anaklah yang beraktivitas, berbuat dan harus aktif sendiri. (Sardiman, 2011: 99). Aktivitas yang dilakukan oleh siswa dalam proses pembelajaran merupakan salah satu faktor penting yang sangat mempengaruhi prestasi belajar. Sardiman (1988:25) menyatakan prestasi belajar sangat vital dalam dunia pendidikan, mengingat prestasi belajar itu dapat berperan sebagai hasil penilaian dan sebagai alat motivasi. Sedangkan Sutratinah Tirtonagoro (2001:43) menyatakan bahwa, "Prestasi belajar adalah penilaian hasil usaha kegiatan belajar mengajar yang dalam bentuk simbol, angka, huruf, atau kalimat yang dapat mencerminkan hasil usaha yang sudah dicapai oleh anak dalam periode tertentu". Djamarah (1994:23) mendefinisikan prestasi belajar sebagai hasil yang diperoleh berupa kesan-kesan yang mengakibatkan 
perubahan dalam diri individu sebagai hasil dari aktivitas dalam belajar. IPA merupakan ilmu pengetahuan atau kumpulan konsep, prinsip, hukum dan teori yang diperoleh dengan menggunakan langkah-langkah ilmiah yang berupa metode ilmiah. Menurut Trianto (2011:151), IImu Pengetahuan Alam adalah pengetahuan yang diperoleh melalui pengumpulan data dengan eksperimen, pengamatan, dan deduksi untuk menghasilkan suatu penjelasan tentang sebuah gejala yang dapat dipercaya. Menurut Abdullah dan Enny (2001:18), IPA merupakan pengetahuan teoretis yang diperoleh atau disusun dengan cara yang khas atau khusus, yaitu dengan melakukan observasi, eksperimentasi, penyimpulan, penyusunan teori, observasi dan demikian seterusnya kait mengkait antara cara yang satu dengan cara yang lain.

Hipotesis yang diajukan dalam penelitian ini adalah langkah-langkah model Siklus Belajar Tri Pramana dapat meningkatkan aktivitas dan prestasi belajar siswa kelas VIII G SMP Negeri 2 Sidemen semester I tahun pelajaran 2017/2018 pada pembelajaran IPA.

\section{METODE PENELITIAN}

Sekolah tempat dilaksanakannya penelitian ini adalah SMP Negeri 2 Sidemen. Subjek penelitiannya yaitu siswa kelas VIII G SMP Negeri 2 Sidemen semester I pada tahun pelajaran 2017/2018 yang berjumlah 26 siswa. Objek penelitian yang peneliti tentukan adalah aktivitas dan prestasi belajar siswa. Penelitian ini dilakukan dari bulan Juli sampai bulan Nopember tahun 2017. Metode pengumpulan data yang digunakan dengan memberikan tes prestasi belajar kepada siswa dan observasi aktivitas siswa, sedangkan metode analisis data dilakukan secara deskriptif. Instrumen dari penelitian ini adalah tes pada masing-masing siklus dan lembar observasi aktivitas siswa beserta rubriknya.

Desain dalam penelitian tindakan kelas ini mempergunakan rancangan dari Hopkins. Penelitian masing-masing siklus dilaksanakan melalui 4 tahapan, yaitu perencanaan penelitian; pelaksanaan tindakan; (3) observasi/ evaluasi; dan (4) refleksi. Penelitian ini 
dilaksanakan pada materi pokok prestasi belajar IPA siswa mencapai Sistem Dalam Kehidupan Tumbuhan. 72 dan ketuntasan klasikalnya (KK) Pada tahap perencanaan peneliti minimal $85 \%$. Hasil belajar siswa membuat RPP, LKS, lembar observasi aktivitas, rubrik penilaian aktivitas serta instrumen penilaian tes. Tahap pelaksanaan tindakan dilakukan dengan pembelajaran di kelas. Pada tahap pengamatan atau observasi, peneliti melakukan pengamatan aktivitas siswa selama pelaksanaan tindakan berlangsung. Pengumpulan data dilakukan dengan menggunakan tes prestasi belajar yang telah tersusun.. Tahapan refleksi dimaksudkan untuk mengkaji secara menyeluruh tindakan yang telah dilakukan, berdasarkan data yang telah terkumpul, kemudian dilakukan evaluasi guna menyempurnakan tindakan berikutnya. Kriteria keberhasilan yang digunakan dalam penelitian ini bila rata-rata $(\bar{X})$ dikatakan meningkat jika rata-rata nilai siklus II lebih besar dari rata-rata siklus I dan memenuhi kriteria ketuntasan minimal yang ditetapkan.

\section{HASIL PENELITIAN DAN PEMBAHASAN}

Berdasarkan karakteristik materi sistem dalam kehidupan tumbuhan, karakteristik siswa di kelas VIII G dan ketersediaan alat dan bahan penunjang praktikum, langkahlangkah pembelajaran yang dilakukan disesuaikan dengan Model Siklus Belajar Tri Pramana, yaitu mengikuti alur P (pratyaksa pramana) - A (Anumana Pramana) - S (sabda pramana). Ringkasan hasil prestasi belajar pada penelitian siklus I dan siklus II disajikan pada tabel berikut:

Tabel 01: Prestasi belajar siswa kelas VIII G SMP Negeri 2 Sidemen Siklus I dan Siklus II

\begin{tabular}{|l|c|c|}
\hline & Siklus I & Siklus II \\
\hline Jumlah nilai & 1880 & 1988 \\
\hline Rata-rata (mean) & 72,30 & 76,46 \\
\hline KKM (Kriteria Ketuntasan Minimal) & 72 & 72 \\
\hline Jumlah siswa yang diremidi & 7 & 4 \\
\hline Jumlah siswa yang diberi pengayaan & 19 & 23 \\
\hline Prosentase ketuntasan belajar & $73,07 \%$ & $88,46 \%$ \\
\hline
\end{tabular}


Hasil analisis aktivitas siswa selama mengikuti pembelajaran IPA menggunakan Model Siklus
Belajar Tri Pramana disajikan pada tabel berikut:

Tabel 02 : Aktivitas Belajar Siswa Siklus I dan Siklus II

\begin{tabular}{|c|c|c|c|c|}
\hline \multirow{2}{*}{ Aktivitas } & \multicolumn{3}{|c|}{ PERTEMUAN KE- } & \multirow{2}{*}{$\begin{array}{c}\text { RATA- } \\
\text { RATA }\end{array}$} \\
\cline { 2 - 4 } & 1 & 2 & 3 & RA \\
\hline (\%) AKTIVITAS SIKLUS I & $\begin{array}{c}71.60 \\
\%\end{array}$ & $\begin{array}{c}71.40 \\
\%\end{array}$ & $\begin{array}{c}72.69 \\
\%\end{array}$ & $71.90 \%$ \\
\hline (\%) AKTIVITAS SIKLUS II & $\begin{array}{c}75.00 \\
\%\end{array}$ & $\begin{array}{c}77.88 \\
\%\end{array}$ & $\begin{array}{c}79.20 \\
\%\end{array}$ & $77.36 \%$ \\
\hline
\end{tabular}

Pada siklus I penggunaan Model Siklus Belajar Tri Pramana belum maksimal dapat dilakukan disebabkan penerapan model tersebut baru dicobakan sehingga guru masih belum mampu melaksanakannya sesuai alur teori yang benar dan siswa belum terbiasa dengan model pembelajaran yang baru. Kekurangan-kekurangan/ kelemahan-kelemahan yang ada dari pelaksanaan tindakan siklus I yang ditemukan yaitu: kemampuan intelektual siswa berbeda satu sama lainnya sehingga pada kegiatan bernalar (anumana), siswa belum terbiasa sehingga membutuhkan waktu yang agak lama, pada tahap pratyaksa siswa kurang cermat membaca prosedur kerja dalam LKS, kegiatan presentasi yang belum berjalan

optimal dan siswa kurang menggali sumber-sumber belajar pada tahap sabda pramana. Sedangkan kelebihan yang ditemukan pada pelaksanaan tindakan siklus I adalah: lebih meningkatkan antusias belajar, siswa dapat berdiskusi dengan teman, berinteraksi dengan temannya dan menciptakan suasana belajar yang kondusif.

Pada siklus ke II perbaikan prestasi belajar siswa diupayakan lebih maksimal dengan peneliti membuat perencanaan yang lebih baik, menggunakan alur dan teori dari Model Siklus Belajar Tri Pramana dengan benar dan lebih maksimal. Kelemahan yang didapat dari pelaksanaan pembelajaran pada siklus II yaitu: guru masih mengamati ada beberapa siswa yang masih tidak memperhatikan temannya ketika kegiatan 
presentasi, namun setelah ditegur mereka kembali memperhatikan kegiatan presentasi. Sedangkan kelebihan yang ditemukan pada pelaksanaan tindakan siklus II adalah: kondisi dan situasi belajar yang lebih kondusif daipada di siklus I sehingga pembelajaran dapat berjalan dengan optimal. Kerja sama siswa mulai terlihat lebih baik, kegiatan praktikum yang sudah mulai berjalan optimal, dan keaktifan siswa mulai terlihat untuk memberikan tanggapan. Tanggung jawab untuk mengerjakan tugas dalam kelompok juga terlihat lebih besar. Siswa mulai aktif untuk memberikan pertanyaan. Kegiatan presentasi yang sudah mulai terlihat berjalan optimal.

Dengan model siklus belajar Tri Pramana guru mampu meningkatkan perannya sebagai fasilitator, motivator, pengajar, pendidik, serta mampu mengembangkan profesionalisme dan mampu melaksanakan pembelajaran yang nyatanyata dapat meningkatkan aktivitas siswa. Siswa dibimbing melakukan suatu percobaan untuk menyelesaikan suatu permasalahan sehingga siswa aktif mengkontruksi pengetahuannya sendiri. Hal ini sesuai dengan pendapat yang disampaikan oleh Elliot (dalam Abimanyu, 2008:22) bahwa "Pembelajaran akan lebih bermakna dan permanen jika siswa diberikan kesempatan aktif membangun pengetahuannya sendiri".

Dari data yang pada siklus II didapat prestasi belajar IPA dan aktivitas siswa siswa sudah memenuhi indikator yang ditargetkan, dengan demikian penelitian tidak dilanjutkan ke siklus berikutnya dan model siklus belajar Tri Pramana dinyatakan berhasil. Hasil penelitian ini sejalan dengan penelitian lain yang sudah dilakukan. Pertama, Subagia dan Wiratma (2008) menyatakan penerapan model siklus belajar Tri Pramana mampu mendorong siswa untuk aktif dan kreatif dalam belajar. Kedua, Raheni (2008) melihat peningkatan kemampuan siswa dalam melakukan pengamatan dan merumuskan masalah sebagai dampak dari penerapan Model Siklus Belajar PAS. Ketiga, Priyanti Antari (2007) melihat kualitas pembelajaran aktif, kreatif, efektif, dan menyenangkan 
dalam pembelajaran kimia sebagai dampak dari penerapan Model Siklus Belajar ASP. Oleh karena itu, hasil penelitian ini berhasil memperkuat penelitian-penelitian tentang model siklus belajar Tri Pramana yang sebelumnya.

\section{SIMPULAN DAN SARAN}

Simpulan yang dapat diperoleh dari hasil penelitian ini adalah peningkatan aktivitas dan prestasi belajar siswa di kelas VIII G SMP Negeri 2 Sidemen semester I tahun pelajaran 2017/2018 pada pembelajaran IPA telah dapat diupayakan. Dari pelaksanaan penelitian terlihat jelas adanya peningkatan dari data awal dengan data di akhir siklus II. Kriteria aktivitas siswa tergolong baik, sebesar $71,90 \%$ di siklus I menjadi $77,36 \%$ di siklus II. Dari prestasi belajarnya terdapat peningkatan dimana rata-rata nilai awal 63 , pada siklus I meningkat menjadi 72,30 dan pada siklus II meningkat menjadi 76,46 . Ketuntasan belajar awal $58 \%$ meningkat menjadi $73,07 \%$ pada siklus I, dan meningkat menjadi $88,46 \%$ pada siklus II. Hal positif yang diperoleh dari penelitian adalah siswa lebih aktif dan mampu bekerja dalam kelompok belajar serta memahami materi IPA secara kontekstual.

Saran yang perlu disampaikan yaitu penggunaan Model Siklus Belajar Tri Pramana semestinya menjadi pilihan dari beberapa model inovatif yang ada mengingat model ini berbasis pada cara-cara belajar tradisional masyarakat Bali. Model Siklus Belajar Tri Pramana telah terbukti dapat meningkatkan kerjasama, menumbuhkan sikap ilmiah dalam penyelidikan, bertindak aktif, bertukar informasi, mengeluarkan pendapat, bertanya, berdiskusi, dan berargumentasi. Walaupun penelitian ini sudah dapat membuktikan efek utama dari Model Siklus Belajar Tri Pramana dalam meningkatkan prestasi belajar IPA dan aktivitas siswa, sudah pasti dalam penelitian ini masih ada hal-hal yang belum sempurna dilakukan, oleh karenanya kepada peneliti lain yang berminat meneliti topik yang sama untuk meneliti bagian-bagian yang tidak sempat diteliti. Selanjutnya untuk adanya penguatan-penguatan, diharapkan 
bagi peneliti lain untuk melakukan penelitian lanjutan guna verifikasi data hasil penelitian.

\section{DAFTAR PUSTAKA}

Abimanyu, Soli. 2008. Strategi Pembelajaran 3 SKS. Jakarta: Dikjen Pendidikan Tinggi Depdiknas.

Djamarah. 1994. Prestasi Belajar dan Kompetensi Guru. Surabaya: Usaha Nasional.

Djamarah, Syaful Bahri. 2002. Prestasi Belajar dan Kompetensi Guru. Surabaya: Usaha Nasional.

Maswinara, I Wayan. 1998. Sistem Filsafat Hindu (Sarva JDharsana Sangraha). Surabaya: Paramita.

Musna, I Wayan. 1986. Pengantar Filsafat Hindu: Sad Dharsana. Denpasar Bali. CV. Kayumas.

Priyanti Antari, I G. A. A. 2007. Kualitas Pembelajaran Kimia dengan Model Siklus Belajar ASP pada Siswa Kelas X3 SMA Negeri 1 Sukasada Tahun Ajaran 2007/2008.
Skripsi. Jurusan Pendidikan Kimia FMIPA Undiksha.

Raheni, Ni Wayan. 2008. Penerapan Model Siklus Belajar PAS untuk Meningkatkan Kemampuan Siswa dalam Mengamati dan Merumuskan Masalah dalam Pembelajaran Kimia Kelas $X$ SMA Negeri 2 Singaraja Tahun Ajaran 2007/2008. Skripsi. Jurusan Pendidikan Kimia FMIPA Undiksha.

Sardiman, A.M. 1988. Interaksi dan Motivasi Belajar-Mengajar Pedoman bagi Guru dan Calon Guru.Jakarta: Rajawali Pers.

Sardiman, A.M. 2011. Interaksi dan Motivasi Belajar-Mengajar. Jakarta: PT. Raja Grafindo Perkasa.

Subagia, I Wayan. 2003a. Model Siklus Belajar Berdasarkan Berdasarkan Konsep Tri Pramana. "Orasi IImiah". Disampaikan Dalamrangka Dies Natalis ke-3 IKIP Negeri Singaraja.

Subagia, I Wayan dan I Gst. Lanang Wiratma. 2007b. 


$\begin{array}{lr}\text { Pengembangan } & \text { Model } \\ \text { Siklus Belajar Berdasarkan } & \text { Kearifan } \\ \text { Potensi-Potensi } & \text { Kokal Masyarakat Bali dalam } \\ \text { Lidang Pendidikan. Laporan } \\ \text { Penelitian Hibah } & \text { Bersaing. } \\ \text { Lembaga } & \text { Penelitian } \\ \text { Universitas } & \text { Pendidikan } \\ \text { Ganesha. }\end{array}$

Subagia, I Wayan dan I Gst.

Lanang Wiratma. 2008.

Penerapan Model Siklus

Belajar Berbasis Tri

Pramana pada

Pembelajaran Sains di

Sekolah. Jurnal Penelitian

dan Pendidikan, volume 41, No.2 (hlm. 272-288).

Tirtonagoro, Sutratinah. 2001.

Penelitian Hasil Belajar

Mengajar. Surabaya: Usaha

Nasional.

Trianto. 2011. Model Pembelajaran

Terpadu. Jakarta: Bumi

Aksara. 